\title{
Online Shopping and its Impact on Customer satisfaction considering the Role of Respondents Trust and Gender Influence
}

\author{
K Francis Sudhakar, Habeeb Syed
}

\begin{abstract}
As like any market place, the success of online shopping depends mainly on customer satisfaction and many other factors that will also increase customers' loyalty towards the channel. This study is mainly done to categorize various such factors that affect the consumer behavior for online shopping. The factors of trust, privacy, convenience, social presence, demographic features like gender where deeply studied for their influence on the consumer behavior. The data collected was over 170 respondents made relevance in identifying the key factors contributing for the behavioral change in online shoppers. The effect of factors like vendor reputation, adequate communication, norms, web designing is also studied. The results indicated that it is necessary to target online buyers with a safer and secured mode of transactions for their re purchase behavior towards the channel. Study also focuses on the demographic feature of gender which says that men are more comfortable and happy with online shopping in India. Hence forth the target segment for the emerging strategies of online shopping would be women.
\end{abstract}

Index Terms: Consumer Behavior, Customer Satisfaction, Gender Influence, Online Shopping, Purchase Behavior, Role of respondents.

\section{INTRODUCTION}

There is rapid growth of electronic world these days. The increase in efficiency and usage of world wide web have improved many factors of economic, social, cultural, scientific and materialistic growth in almost every sector and part of the world. The commercial transactions between the countries, knowledge gathering and sharing throughout the world have increased during the past two decades at a rapid rate. Through this many new convenient ways for almost anything and everything evolved in this cyber world. One such example considered for this study is Online Shopping and this similar type of study will be suitable to any industry

Online shopping is a platform where consumers can directly buy the goods and services from the sellers, through internet. Online shopping can be of many types business to business type, business to consumer type, consumer to consumer type. The place where these business activities take place is called an online store. The online stores provides the customers with the product catalogues, price variations, product features, payment options and many other flexible features which make the buyer feel ease of shopping. Now with this feature any one can shop at any time for anything they like, by just being at the place they are. There are many online shopping websites like Jabong, Myntra, Flipcart, Amazon, Shop Clues.

Most of the people are interested in online shopping, but still there are certain obstacles to this way of buying. The purpose of this study is to study the factors influencing the online shopping behavior of the consumers. The main purpose is to study the factors affecting the online shopping behavior. At the same time balanced observations on how the major factors effect on online shopping behavior of consumers are carried out. A relationship between demographic features and trust towards online purchase are analyzed and studied. The factors are categorized into groups that would show a common effect on the purchase decision of the consumers.

Study is carried out for following reasons:

- To gain an in-depth understanding of online retail market dynamics in India.

- To obtain research based business decision and add weight to presentations and marketing materials.

- The forecasts to assess how the market is predicted to develop in future.

- To understand the various factors which are contributing the growth and those which are/will be critical for the industry performance in the near future.

\section{THEORETICAL BACKGROUND}

The study analyses various factors contributing their affect on online purchasing behavior. Various factors considered in the study are Internal Norms, External Norms, Communication, Security, Enjoyment, Convenience, Online Innovativeness, Vendor reputation, self efficacy, social presence, visual design, information design and privacy. Hence forth all the factors that are considered into the study have their own significance and all those effects are studied through the secondary and primary research. 


\begin{tabular}{|c|c|c|c|}
\hline $\begin{array}{l}\text { S } \\
\text { No. }\end{array}$ & Author(s) Name & $\begin{array}{l}\text { Year of } \\
\text { Publication }\end{array}$ & Essence \\
\hline 1. & Rose, Tamimi & 2008 & $\begin{array}{l}\text { Study says that gender doesn't show any effect on frequency of online } \\
\text { buying or variation in buying decision through online. }\end{array}$ \\
\hline 2. & Liu and Sandra & 2010 & $\begin{array}{l}\text { Usefulness, enjoyment and ease of use are the main factors that affect } \\
\text { the use of online channel for information search and online shopping. } \\
\text { Avoiding risk is the main factor that affect online shopping. }\end{array}$ \\
\hline 3. & $\begin{array}{l}\text { Margaret, Jha and } \\
\text { Et.al }\end{array}$ & 2010 & $\begin{array}{l}\text { In this study five virtual elements namely sense, interaction, pleasure, } \\
\text { flow, community relationship is analyzed. In the absence of physical } \\
\text { differentiators, the sense acts as the main factor of influence in } \\
\text { purchase decision. }\end{array}$ \\
\hline 4. & Liu, Sandra and Et.al & 2011 & $\begin{array}{l}\text { Study says innovative adoption has not shown sustained growth in the } \\
\text { online shopping. Clear understanding between various normative links } \\
\text { of channels would have given a better way to online shopping } \\
\text { adoption. }\end{array}$ \\
\hline 5. & Kim and Mathew & 2011 & $\begin{array}{l}\text { Findings indicate that hedonic shopping motivation is a major } \\
\text { predictor of exploratory information seeking and impulse buying. } \\
\text { Studies also say that online shopping behaviors affected by hedonic } \\
\text { shopping motivation affect pre-purchase browsing time, which has a } \\
\text { positive relationship with online buying frequency. }\end{array}$ \\
\hline 6. & Sajjad Nazir and Et.al & 2012 & $\begin{array}{l}\text { The study was carried on various physiological and psychological } \\
\text { factors. The study shows that the secrecy and privacy are the major } \\
\text { factors that influence the online shopping behavior. Along with theses } \\
\text { the price, trust and convenience are also found to be important for the } \\
\text { online purchase. }\end{array}$ \\
\hline 7. & Ahmed and sarigo & 2013 & $\begin{array}{l}\text { Study says that online shopping adoption changes with place which } \\
\text { has high developed in infrastructure to low ones. Thus a better online } \\
\text { shopping strategy would help for further established use of online } \\
\text { shopping in less developed countries. }\end{array}$ \\
\hline 8. & Kevin and Saleem & 2013 & $\begin{array}{l}\text { In this the physiological responses associated with cognition, on } \\
\text { various navigations where recorded and studied. The importance for } \\
\text { these is tracked out and web navigations are also considered important } \\
\text { that affect the online shopping. }\end{array}$ \\
\hline 9. & Taweerat Jiradilok & 2014 & $\begin{array}{l}\text { The study was carried out measuring the factors influencing the } \\
\text { motivating online purchase intentions. The result speaks about the } \\
\text { experience and inexperienced online purchases. }\end{array}$ \\
\hline 9. & $\begin{array}{l}\text { Songpol Kulviwat and } \\
\text { Yong Zhang }\end{array}$ & 2015 & $\begin{array}{l}\text { This study examines the emotional antecedents that predict flow in } \\
\text { consumers when engaged in online shopping by empirically } \\
\text { comparing the three well-known emotion theories to determine their } \\
\text { effectiveness in predicting online flow. }\end{array}$ \\
\hline 10. & $\begin{array}{l}\text { Sahar Karimi and } \\
\text { Et.al }\end{array}$ & 2016 & $\begin{array}{l}\text { The study explores how the online purchase process is affected by } \\
\text { individual decision-making style and knowledge of product. Presented } \\
\text { four archetypes of online shoppers throughout the decision making } \\
\text { purchasing process. }\end{array}$ \\
\hline
\end{tabular}

In this study, for a detailed knowledge about Information system success the DeLone and McLean model (2002, 2003) is studied which covers different ideas of evaluating the Information system. The model consists of six interrelated dimensions of IS success: information, system and service quality, (intention to) use, user satisfaction, and net benefits. The arrows demonstrate proposed associations between the success dimensions. The model can be interpreted as follows: A system can be evaluated in terms of information, system, and service quality; these characteristics affect the subsequent use or intention to use and user satisfaction. As a result of using the system, certain benefits will be achieved. The net benefits will (positively or negatively) influence user satisfaction and the further use of the information system.
Research says that bonds are emotional, economical, psychological and physical attachments in a relationship. They are connected through association and interaction and these serve parties together with a relational exchange. Dividing the consumer behavior to loyalty, they are of three levels relationship tactics: Financial, social and structural bonding tactics. Also these three affect the online consumer behavior. 


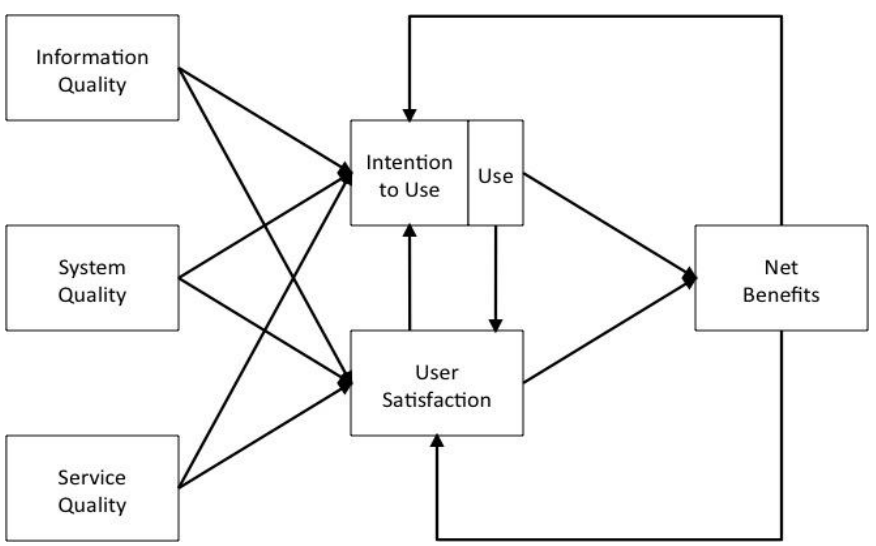

Figure 1. DeLone and McLean Updated model $(2002,03)$

\section{RESEARCH HYPOTHESIS}

The study is evolved round the three main objectives. To attain these objectives, the hypotheses being established for every objective are as follows:

Objective i): to analyzing the role of respondents' trust while purchasing online.

$\mathrm{H}_{0}$ : There is no significant relationship between trust and time spent on online shopping.

Objective ii): to analyze Demographic factor (Gender) influence on online shopping

$\mathrm{H}_{0}$ : Female respondents do more online shopping than male

Objective iii): to analyze the relationship between age and average time spent shopping online.

$\mathrm{H}_{0}$ : Age have any influence on average time spent online shopping

Where $\mathrm{H}_{0}$ is the null hypothesis for the objectives

\section{RESEARCH DESIGN}

Study was used to examine the online shopping behavior of approximately 170 respondents who filled the closed ended questions. Data was gathered from different population of students, employees, teachers and households from general public, so that all sects of responses can be noted for better research. Questionnaire was circulated among 100 men and at high importance and 5 at unimportant, 1 at essential and 5 at non essential, 1 means a nothing and 5 means a lot, 1 at worthless and 5 at valuable. It should be ensured that responses are the validity of the research done.

Hence forth Likert scale is the research instrument used. For the data analysis and interpretation SPSS software is used. The independent variables are formed through the factor analysis done on the data collected which is based on various factors Internal Norms, External Norms, Communication, Security, Enjoyment, Convenience, Online Innovativeness, Vendor reputation, self efficacy, social presence, visual design, information design and privacy. The primary dependent variable in the data is the AVG Time spent shopping online. T-Test is used to evaluate the results of gender and online shopping behavior relation. ANOVA is used to find the effect of security on online shopping which provides trust to the shoppers. 70 women approximately. They have been asked to answer the questions based on the Likert scale ratings starting from 1

\section{DATA INTERPRETATION AND ANALYSIS}

Data analysis is carried out on the data taken from the respondents who were given the questionnaires. The demographic summary is as follows.

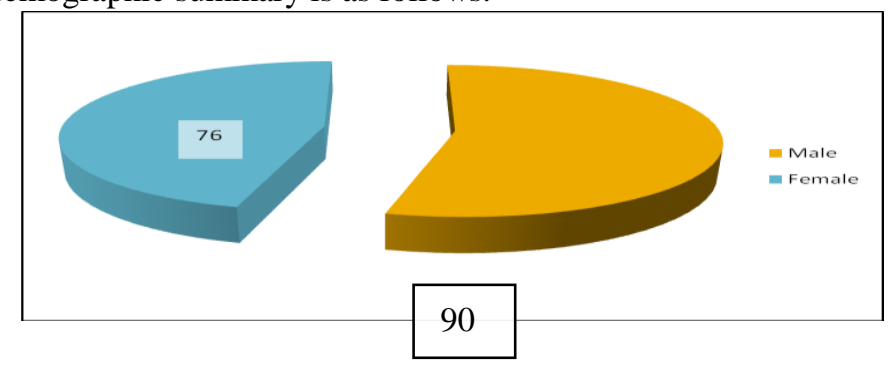

\section{Chart 1. Demographic summary of respondents}

I. First Hypothesis: Analyzing the role of respondents' trust while purchasing online.

II.

To make this study the relationship between respondents' trust on buying things online and the average time they spend on the online shopping. Trust depends on security in online shopping (assumption made for the study)

Table 1. Anova output

\section{ANOVA}

\begin{tabular}{|l|r|r|r|r|r|}
\cline { 2 - 6 } \multicolumn{1}{l|}{ Security } & \multicolumn{1}{|c|}{ Sum of } \\
\hline & Squares & df & \multicolumn{1}{c|}{$\begin{array}{c}\text { Mean } \\
\text { Square }\end{array}$} & \multicolumn{1}{c|}{ F } & Sig. \\
\hline $\begin{array}{l}\text { Between } \\
\text { Groups }\end{array}$ & 20.510 & 34 & .603 & 1.250 & .189 \\
Within Groups & 59.841 & 124 & .483 & & \\
Total & 80.351 & 158 & & & \\
\hline
\end{tabular}

Hence we can say by observing the sig value which is greater than 0.05 , which null hypothesis stating no relationship between trust and time spent on online shopping can be rejected. Hence, we can say that there is a significant relationship between trust and time spent buying online.

III. Second Hypothesis: To analyze the Demographic factors influence on online shopping

The demographic factor considered here is the Gender. The study is done to analyze whether the gender shows any effect on online purchasing decision or not.

Hence from the above independent sample test table we get sig. value greater than 0.05 . Hence we consider the first row i.e equal variance assumed to evaluate the further results. Now the sig (2-tailed ) value is greater than .05. Hence we can state that null hypothesis is accepted. Hence we can say that female respondents are more interested in online shopping than male.

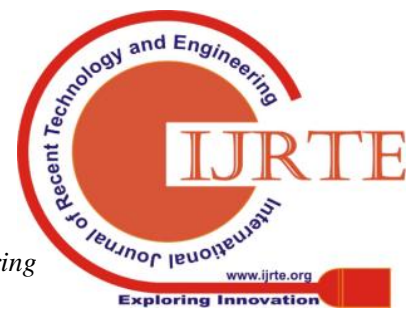


Online Shopping and its Impact on Customer satisfaction considering the Role of Respondents Trust and Gender Influence

\section{TABLE 2: T TEST ANALYSIS}

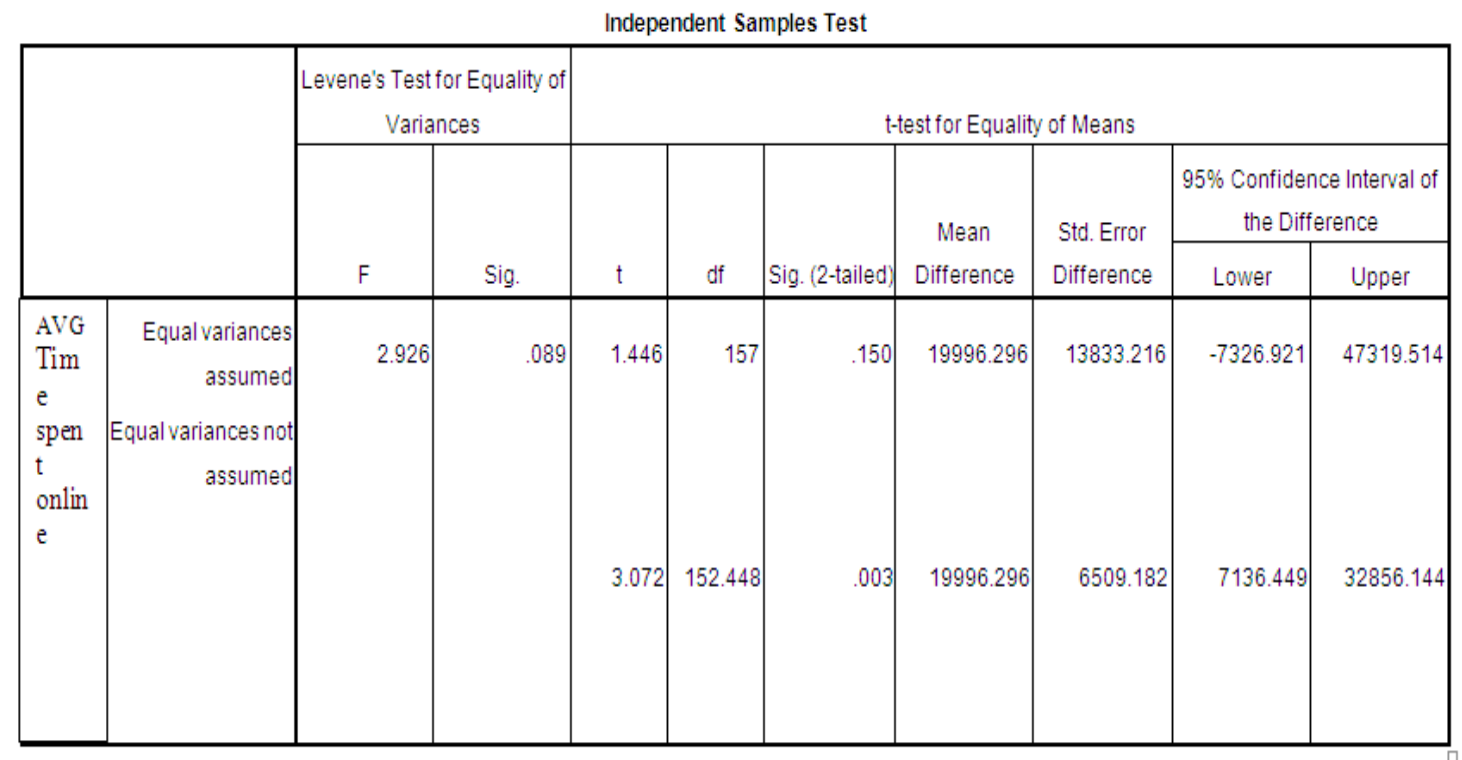

Table 3: Crass Tab For the Age and Avg. Spent on Online Shopping

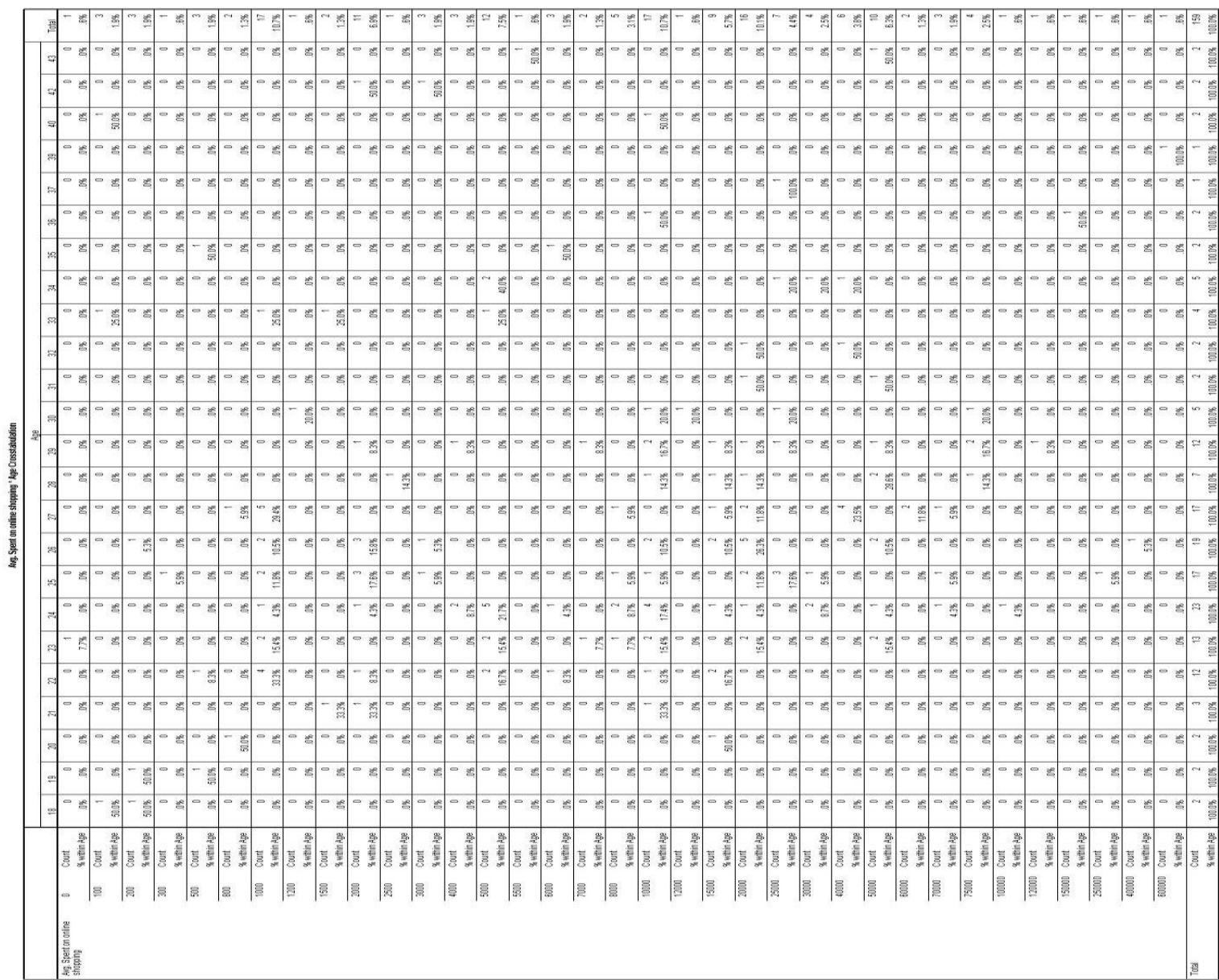


IV. Third Hypothesis: To analyze the relationship between age and average time spent shopping online.

Study is done through cross tabulation method which analyses the relationship between age and average time spent shopping online. The following are the results from the Cross tabulation using the chi-square test. Here in this cross tabulation Age is the independent variable and average time spent on online shopping is the dependent variable. Age is a taken as ordinal data. The percentages of each age response is shown as below in every case of online shopping.

The above tables shows the percentage downward results of every age group towards avg. time spent on online shopping.

By comparing one column with the other column, we could draw an initial conclusion that different age people show different interest on online shopping. However, we are interested more in inferring the sample finding to the target population, the above conclusion must be tested for statistical significance by the Chi-square test shown below

Table 4: chi - Square test output Chi-Square Tests

\begin{tabular}{|l|r|r|r|}
\hline & Value & \multicolumn{1}{c|}{ df } & \multicolumn{1}{|c|}{$\begin{array}{c}\text { Asymp. Sig. } \\
\text { (2-sided) }\end{array}$} \\
\hline Pearson Chi-Square & $1.066 \mathrm{E}$ & 782 & .003 \\
Likelihood Ratio & 411.029 & 782 & 1.000 \\
Linear-by-Linear & 6.249 & 1 & .012 \\
Association & 159 & & \\
N of Valid Cases & & & \\
\hline
\end{tabular}

a. 840 cells $(100.0 \%)$ have expected count less than 5 . The minimum expected count is .01 .

Here in this cross tabulation the asymp. Sig (2 sided) value should be greater than 0.05 to reject the null hypothesis. But the results from the above table show that the value is 0.003 which is less than 0.05. Hence the null hypothesis is not rejected. This implies that there is significant relation between the age and avg. time spent shopping online. From the above cross tab we get to know that people aged 22-29 spend more on online shopping when compared to other age people. Whereas people aged 18-21 show the least time spent on online shopping. Thus a significant relationship can be shown between avg. time spent and age of the respondent.

\section{FINDINGS AND SUGGESTIONS}

1. The study reveals that Security, Vendor reputation, Self efficacy, Privacy and convenience play a major role in affecting consumer behavior for online shopping. The study also says that the web designing factors like navigation design, visual design and information design also have greater significance on purchase decisions of the online buyers.

2. The study also reveals that men are more attracted towards online shopping than the women. The study also says that trust is the most important factor for online shopping behavior. Trust arises through secured way of shopping which is considered as the security factor in the study.

The results of the study say that people aged 22-29 spend more time on online shopping than any other age group. This might be because of the more internet access they have, the more attraction towards the technology, higher risk taking capability and many others.

\section{SugGeSTIONS}

1. The more user friendly the channel of online shopping would be, the more the re purchase decision would be. It is very important to maintain the ease of shopping through the channel.

2. Trust is very important of any company. Unless the perfect vendor reputation is maintained, which significantly indicates the quality of product, the consumers won't show interest towards the channel. Hence maintaining proper vendor reputation and relationship is very important.

3. With the increasing literacy rate and growing population by at least next five years the e-tailing can be focus towards the age groups of 30 and above with the same or increased customer base of 20-29 aged group people.

4. The proper target segment for the future would be women of age 25-30. Hence a proper communication plan, easy way of access to the channel may lead to good profits.

\section{CONCLUSION}

Any sort of shopping would be a fun loving, easy, comfortable, time saving and comfortable way of shopping if more importance in channel designing is given to proper web designing, secured way of transacting, appropriate and adequate communication being provided to the customers. The vendor reputation has its own significance in attracting the consumers to the channel. The consumer behavior for online shopping is mainly based upon the trust that the channel or the seller provide to them. This would be through maintaining security and privacy of consumer information. As such the male are more attracted to the online shopping, the new and better target segment for the new emerging online shopping strategies would be women. This is to draw the women consumers who are more impulsive in buying to the online shopping zone.

\section{REFERENCES}

1. Chiu, C. M., Lin, H. Y., Sun, S. Y., \& Hsu, M. H., "Understanding customers' loyalty intentions towards online shopping: an integration of technology acceptance model and fairness theory". Behaviour \& Information Technology, 28(4), 2009, 347-360.

2. Sebastianelli, R., Tamimi, N., \& Rajan, M. "Perceived quality of online shopping: does gender make a difference?". Journal of Internet Commerce, 7(4), 2008, 445-469.

3. Aziz Sajid, Saajad Nazir and etl., IJCSI International Journal of Computer Science Issues, Vol. 9, Issue 3, No. 1, 2012.

4. Sahar Karimi et.al. , "The effect of prior knowledge and decision-making style on the online purchase decision-making process", Decision Support Systems, 0167-9236(p), 2013.

5. Hanjun Koa, Jaemin Jungb, JooYoung Kimc \& Sung Wook Shimd a Kookmin University, Korea b University of West Florida "Cross-Cultural Differences in Perceived Risk of Online Shopping". 
ISSN: 2277-3878, Volume-X, Issue-X, don’t delete Top \& Bottom Header, \& Fill up Manuscript details (It Page, Bottom, Left Side)

6. Ojha, A., Sahu, G. P., \& Gupta, M. P. "Antecedents of paperless income tax filing by young professionals in India: an exploratory study", Transforming Government: People, Process and Policy, 3(1), 2009, 65-90

7. Alhassan G. Abdul-Muhmin, "Repeat purchase intentions in online shopping: The role of satisfaction, attitude and online retailers performance", Journal of International Consumer Marketing, 0896-1530(p) 1528-7068(e), 2010

8. Kevin Wise a , Saleem Alhabash b \& Petya Eckler ca University of Illinois at Urbana-Champaign, Urbana, Illinois, USA b Michigan State University , East Lansing, Michigan , USA. "Window" Shopping Online: Cognitive Processing ofGeneral and Specific Product Windows".

9. Tze-Hsien Liao a,1, Ching-Jui Keng b, a Department of Business Management, Tatung University,No.40,Sec.3, Zhongshan N.Rd.,Zhong-shan District,Taipei City 10452,Taiwan,ROC b Department of Business Management, National Taipei University of Technology,No.1,Sec.3,Zhongxiao E.Rd.,Da-an District,Taipei City 10608, Taiwan,ROC "Online shopping delivery delay: Finding a psychological recovery strategy by online consumer experiences.

10. Delone, W. H., \& McLean, E. R., "The DeLone and McLean model of information systems success: a ten-year update", Journal of management information systems, 19(4), 2003, 9-30.

11. Understanding how US online shoppers are reshaping the retail experience http://www.pwc.com/en_us/us/retail-consumer/publications/assets/pwc -us-multichannel-shopping-survey.pdf

12. http://www.internetretailer.com/2013/01/11/indias-online-retail-market -could-double-size 